\title{
Molecular characterization of hepatitis c virus in multi-transfused Colombian patients
}

\author{
Diana di Filippo ${ }^{1}$, Fabian Cortes-Mancera ${ }^{1,2}$, Mauricio Beltran ${ }^{3}$, Maria Patricia Arbelaez ${ }^{4}$, Sergio Jaramillo ${ }^{5}$, \\ Juan Carlos Restrepo ${ }^{1,5}$, Gonzalo Correa ${ }^{1,5}$ and Maria-Cristina Navas ${ }^{1 *}$
}

\begin{abstract}
Background: Hepatitis C virus (HCV) infects 170 million persons worldwide and is a public health problem. Considering that HCV is principally transmitted by exposure to infected blood, multi-transfused patients constitute one of the most important risk groups in developing countries. To explore the dynamics of this infection in Colombia, we performed a study to determine the genotypes of HCV in a cohort of multi-transfused patients.

Results: The serum samples from patients positive for anti-HCV were evaluated for HCV RNA by nested-PCR of the 5'untranslated region (5'UTR). Viral genotype was determined by RFLP and/or automated sequencing. HCV subtype $1 \mathrm{~b}$ was found in eight cases (66.7\%) and subtype $1 \mathrm{a}$ in two cases (16.7\%); seven isolates of subtype $1 \mathrm{~b}$ were obtained from patients who had received the first transfusion before 1986. Either genotypes $2 \mathrm{~b}$ (8.3\%) or 3a (8.3\%) were found in the remaining positive specimens.

Conclusions: This is the first HCV genotyping study developed in multi-transfused patients in Colombia where HCV subtype $1 \mathrm{~b}$ was the most prevalent. The mutation G235A in the $5^{\prime} \mathrm{UTR}$ of three isolates generated an additional restriction site and an RFLP pattern different from those previously described for genotype 1 .
\end{abstract}

\section{Background}

HCV infection is a global public health problem worldwide. The virus persists in 60 to $85 \%$ of infected persons and can lead to end-stage liver diseases and death. Indeed $\mathrm{HCV}$ is a principal cause of cirrhosis and liver cancer and a major indication for liver transplantation [1,2].

$\mathrm{HCV}$ is a single-stranded RNA virus classified into the family Flaviviridae, genus Hepacivirus [3]. Six major genetic groups and numerous subtypes have been described with different geographical distributions, transmission routes and response to antiviral treatments [2,4-7]. Subtypes $1 \mathrm{a}, 1 \mathrm{~b}, 2 \mathrm{~b}$ and $3 \mathrm{a}$ are the most prevalent $[8,9]$; subtype $1 \mathrm{~b}$ is predominantly identified among individuals with history of blood transfusions ; subtypes 1a and 3a are becoming more prevalent in former intravenous drug users (IDU) [10-13].

In developed countries, voluntary blood donation, blood donor education, history-based donor selection

\footnotetext{
* Correspondence: mcnavasn@gmail.com

'Grupo de Gastrohepatologia, Sede de Investigacion Universitaria (SIU), Universidad de Antioquia, Carrera 53 \# 61-30, Laboratorio 434, Torre 2, Medellin, Colombia

Full list of author information is available at the end of the article
}

and universal blood donor laboratory screening have resulted in improved blood safety and reduced residual risk for transfusion-transmissible infections (TTI), including HCV $[14,15]$. However, TTI are still a public health problem in developing countries [16].

A cross-sectional study carried out in Colombia showed that the overall prevalence of HCV infection among 500 multi-transfused Colombian patients was 9\%; the main risk factors were being a patient with hemophilia, receiving transfusions before 1995 and having received $\geq 48$ units of blood components [17].

To better understand the epidemiology of $\mathrm{HCV}$ in Colombia, we characterized the HCV genotypes and subtypes in this cohort of multi-transfused patients.

\section{Results and discussion}

The study population included 45 patients with $\mathrm{HCV}$ antibodies from the cohort of the cross-sectional study of multi-transfused patients (33 males, 12 females, median age 50 years, median age of first transfusion 14 years). This study was carried out in four hospitals in the two largest cities in Colombia, Bogota and Medellin. 
The HCV genome was detected by 5'UTR nested RTPCR in 12 (26.6\%) of the 45 samples obtained from anti$\mathrm{HCV}$ positive multi-transfused patients. The yield rate could be due to viral clearance, low viral load and/or the long period of sample storage. A similar percentage, $28.8 \%$, of $\mathrm{HCV}$ genome detection in anti-HCV positive samples was reported in other study [18]; moreover the probability of unsuccessfully PCR amplification is associated with viral loads $<100$ copies $/ \mathrm{ml}$ [8].

Ten of the 12 patients $(83.3 \%)$ received the first transfusion before 1993, the date when testing for $\mathrm{HCV}$ in blood transfusions become mandatory in Colombia [17]. Clearly, the risk of HCV infection diminished dramatically in the cohort after 1995. Additionally, all the patients with hemophilia had received cryoprecipitate and 3 of them had also received whole blood (Table 1); indeed the transfusion of whole blood was identified as a risk factor in the multivariate analysis of the cohort [17].

These results are consistent with the risk of receiving an $\mathrm{HCV}$ positive blood component in Colombia estimated by 1994 (25.4 / 10.000 donations) and the HCV screening coverage in blood donors reported in the same period (67\%). However, the screening coverage in 1997 was 100\% and consequently this risk

Table 1 HCV genotype distribution in Colombian multitransfused patients

\begin{tabular}{|c|c|c|c|c|}
\hline $\begin{array}{l}\text { Code of } \\
\text { samples }\end{array}$ & Genotype & $\begin{array}{c}\text { Number of } \\
\text { transfused units/ } \\
\text { Blood components }\end{array}$ & $\begin{array}{l}\text { Year of the } \\
\text { first } \\
\text { transfusion }\end{array}$ & $\begin{array}{c}\text { Diagnostic } \\
\text { category }\end{array}$ \\
\hline $\begin{array}{c}\text { HCV } \\
\text { COL_208 }\end{array}$ & $1 \mathrm{a}$ & $9114^{*}$ & 1950 & Hemophilia \\
\hline $\begin{array}{c}\text { HCV } \\
\text { COL_188 }\end{array}$ & $1 b$ & $80^{*}$ & 1960 & Hemophilia \\
\hline $\begin{array}{c}\text { HCV } \\
\text { COL_178 }\end{array}$ & $1 b$ & $42^{*}$ & 1962 & Hemophilia \\
\hline $\begin{array}{c}\text { HCV } \\
\text { COL_173 }\end{array}$ & $1 b$ & 1992 & 1972 & Hemophilia \\
\hline $\begin{array}{c}\text { HCV } \\
\text { COL_XX6 }\end{array}$ & $1 b$ & 2710 & 1974 & Hemophilia \\
\hline $\begin{array}{c}\text { HCV } \\
\text { COL_172 }\end{array}$ & $1 b$ & 1344 & 1975 & Hemophilia \\
\hline $\begin{array}{c}\text { HCV } \\
\text { COL_175 }\end{array}$ & $1 a$ & 1704 & 1980 & Hemophilia \\
\hline $\begin{array}{c}\text { HCV } \\
\text { COL_478 }\end{array}$ & $1 b$ & 11 & 1951 & $\begin{array}{c}\text { Acute } \\
\text { bleeding }\end{array}$ \\
\hline $\begin{array}{c}\text { HCV } \\
\text { COL_224 }\end{array}$ & $1 b$ & 20 & 1986 & Hemodyalisis \\
\hline $\begin{array}{c}\text { HCV } \\
\text { COL_278 }\end{array}$ & $3 a$ & 10 & 2002 & Hemodyalisis \\
\hline $\begin{array}{c}\text { HCV } \\
\text { COL_120 }\end{array}$ & $2 b$ & 10 & 1998 & $\begin{array}{l}\text { Oncologic } \\
\text { disease }\end{array}$ \\
\hline $\begin{array}{c}\mathrm{HCV} \\
\mathrm{COL} \times \mathrm{XX} 1\end{array}$ & $1 b$ & 12 & 2002 & $\begin{array}{c}\text { Oncologic } \\
\text { disease }\end{array}$ \\
\hline
\end{tabular}

*Including whole blood. decreased to $0 / 10.000$ donations that year. This data demonstrates the value of direct and indirect strategies to improve transfusion policy [16,19]

To analyze the distribution of the different $\mathrm{HCV}$ genotypes in this population, we first performed an analysis by RFLP. A comparison among RFLP restriction patterns obtained and those generated by bioinformatics with GenBank sequences allowed the identification of five isolates as subtype $1 \mathrm{~b}$, two as subtype 1a, one as genotype 2 and one as genotype 3 . In some samples, the viral subtype could not be established by this method due to the similarity between patterns. Unexpectedly, three isolates (HCVCOL_172, 478, XX1) showed a restriction pattern similar to that of genotype 6 (Figure 1).

To verify the results obtained by RFLP, the PCR products of eight isolates (HCVCOL_175, 224, 120, 278, XX6, 172, 478 and XX1) were directly sequenced using primers 940 and 211. Analysis of these sequences by BLAST made it possible to confirm the subtypes $1 \mathrm{a}$ and $1 \mathrm{~b}$, and to determine the subtypes $2 \mathrm{~b}$ and $3 \mathrm{a}$. Moreover, the three isolates with the unexpected RFLP pattern (HCVCOL_172, 478 and XX1) were identified as genotype 1 with a similarity of $98 \%$.

The phylogenetic tree using the neighbor-joining method showed the expected clades for the $\mathrm{HCV}$ prototypes (Figure 2). Isolates HCVCOL_175, 224, 120, 278 and XX6 were grouped into the same genotypes/subtypes previously designated by RFLP and BLAST. On the other hand, the isolates HCVCOL_172, 478 and XX1 were grouped in genotype 1 based on phylogenetic analysis. These results suggest a limitation of the 5'UTR RFLP-based genotyping method to discriminate the pattern of some strains of genotype 1 . The inferring consensus tree showed a similar topology; indeed, the clade of genotype 1 was supported by high bootstrap values. This finding was confirmed by maximum parsimony analyses (data not shown).

To assess the differences observed between the techniques used to identify the HCV genotypes, the sequences of the strains HCVCOL_172, 478, XX1 were aligned with $\mathrm{HCV}$ sequences previously reported in patients from Argentina and Uruguay (Figure 3). The Colombian isolates with the unexpected RFLP pattern were grouped into one sub-clade together with isolates of genotype 1, subtype $1 \mathrm{~b}$ from Argentina and Uruguay [20]. Based on the HCV genome sequence described by Choo et al. [3], two unique substitutions were found; these mutations were localized at nucleotides -96 and -235 . The former substitution corresponds to the change from adenine to guanine (A96G) and the second one to the transition G235A. When the substitutions were compared with the sequences recognized by each restriction enzyme used in the RFLP assay, a polymorphism (GTGC to GTAC) was detected that correlates with the substitution G235A 

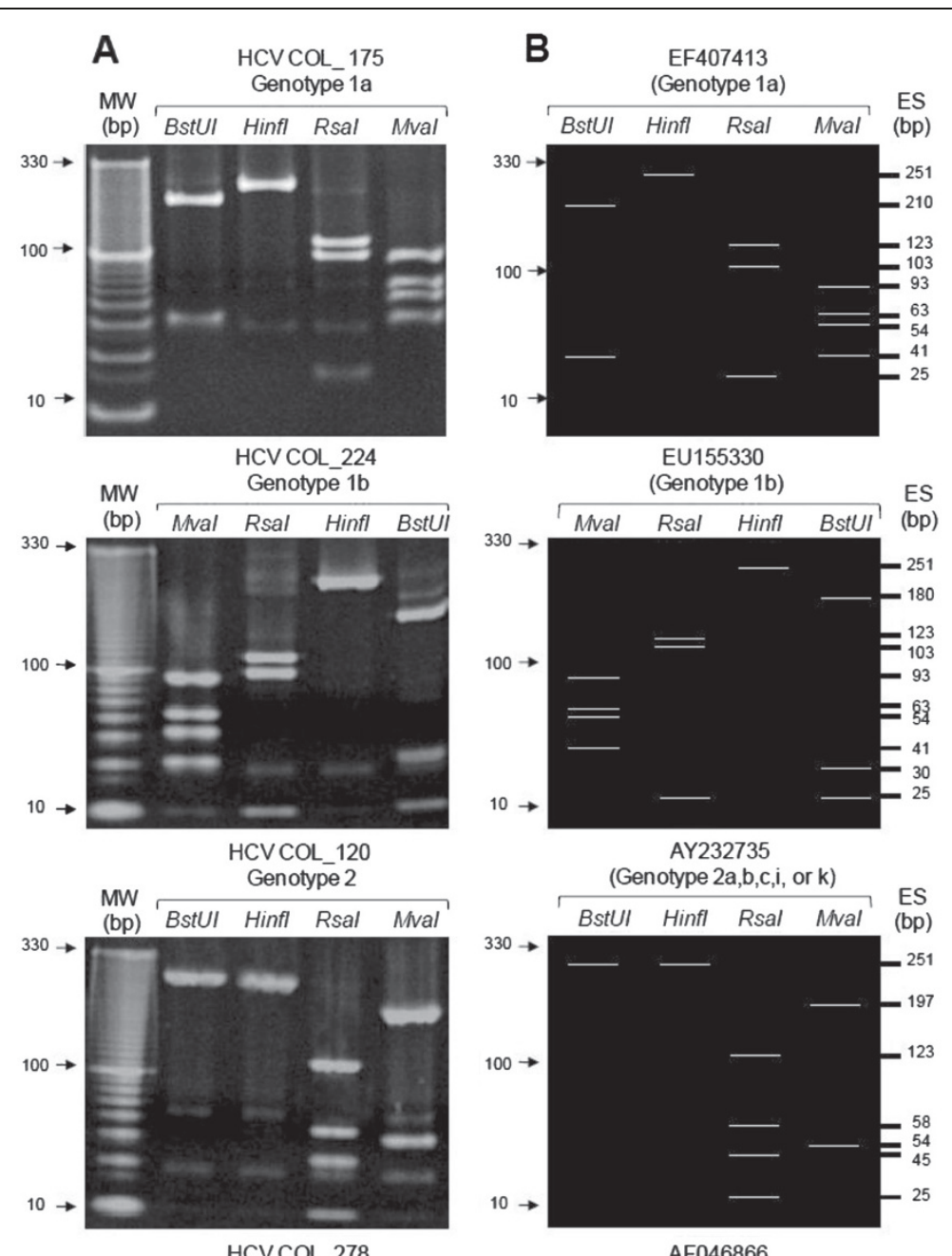

AF046866

(Genotype 3a,b,c, or k)

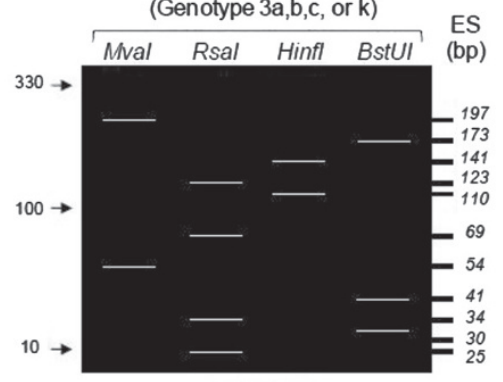

EF424629

$10 \rightarrow-\frac{}{\text { HCV COL XX1 }}$

MW Genotype 6
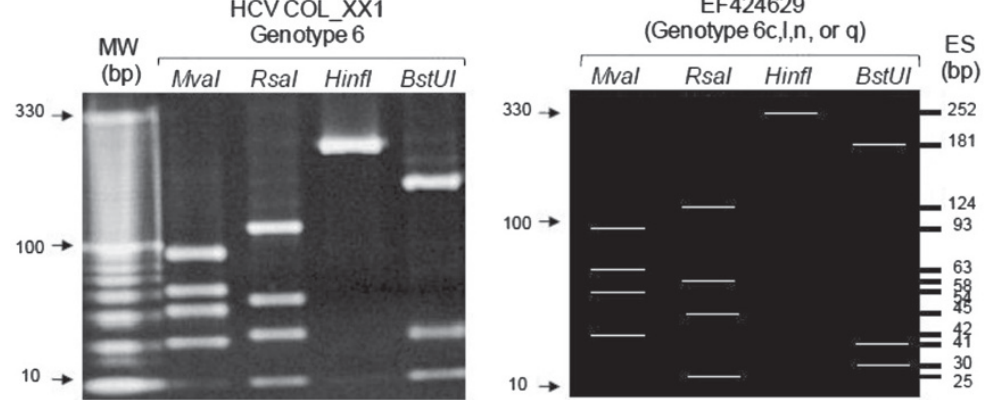

Figure 1 (See legend on next page.) 
(See figure on previous page.)

Figure 1 Identification of patterns obtained by restriction endonuclease digestion of HCV 5'UTR sequences. WM: Molecular Weight marker 10 bp ladder. A. Restriction patterns of samples generated by RFLP. B. In silico restriction patterns of Genbank sequences generated by Bioedit software; Genbank accession numbers (EF407413, EU155330, AY232735, AF046866, EF424629). ES: Expected size of digested fragments.

generating a restriction site for the enzyme RsaI (GT $\underline{\text { CC }}$ to GTAC), modifying the RFLP pattern of genotype 1 . This polymorphism had been previously described in samples obtained from patients with chronic HCV infection in Argentina and Uruguay [21].

On the other hand, relevant substitutions were observed at positions -96 and -135 positions (G96A, C135A) in some strains, as well as an insertion of adenine at nucleotide $-66(66 \mathrm{~A})$ in one isolate (data not shown). All these mutations were located in domain III of the Internal Ribosome Entry Site (IRES), a secondary structure of the viral genome that mediates recognition by the $40 \mathrm{~S}$ ribosomal subunit and the binding of the translation initiation factor 3 (eIF3). Further studies are necessary to determine the biological consequences of these mutations [22-24].

Based on the results of the phylogenetic analysis and/ or RFLP, the circulation of HCV genotype 1, subtypes $1 \mathrm{~b}$ $(8 / 12,66.7 \%)$ and $1 \mathrm{a}(2 / 12,16.6 \%)$, genotype 2 , subtype $2 \mathrm{~b}(1 / 12,8.3 \%)$ and genotype 3 , subtype $3 \mathrm{a}(1 / 12,8.3 \%)$ was confirmed in this high risk population (Table 1).

A number of studies were carried out previously to describe the $\mathrm{HCV}$ distribution in donors and patients with chronic liver diseases in Colombia [18,25-28]. Subtype $1 \mathrm{~b}$ was the most frequently found in all these studies, although only two such studies correspond to phylogenetic analyses of HCV samples. In the first study, Mora et al. [18] explored the HCV genotype distribution among 53 samples from blood donors. As described in other South American countries, subtype $1 \mathrm{~b}$ was the most prevalent in this donors population (82.8\%); interestingly, this prevalence is one of the highest described among different studies performed worldwide. The distribution of the other subtypes and genotypes in this population donor was 1 a $5.7 \%, 2 \mathrm{a} 5.7 \%, 2 \mathrm{~b} 2.8 \%$, and $3 \mathrm{a} 2.8 \%$. The second study corresponds to the description of HCV genotypes in samples of liver tissue obtained from patients with end-stage liver diseases. The strains were grouped into subtypes $1 \mathrm{a}$ (one sample) and $1 \mathrm{~b}$ (three samples) [29].

As mentioned above, HCV subtype $1 \mathrm{~b}$ is mostly found among persons with a history of blood transfusion and among older individuals. Moreover, several studies have linked $\mathrm{HCV}$ subtype $1 \mathrm{~b}$ to patients with bleeding disorders $[30,31]$. In the present study genotype 1 was the only genotype characterized in patients with hemophilia: five patients were infected with subtype $1 \mathrm{~b}$ and two patients had subtype 1a (Table 1). The five patients in other diagnostic categories (hemodialysis, acute bleeding or oncologic illnesses) were infected with three different genotypes/subtypes, $1 \mathrm{~b}$ ( 3 patients), $2 \mathrm{~b}$ (1 patient) and 3a (1 patient) suggesting a more diverse origin of their infections.

Furthermore, seven isolates of subtype $1 \mathrm{~b}$ characterized in our study were obtained from patients who had received their first transfusion before 1986. HCV screening of blood donors became mandatory in Colombia in 1993; but its universal coverage was not reached until 1997 [32].

In fact, Mora et al. [18] estimated that HCV subtype1b was introduced in Bogota around 1950 and spread exponentially in the period 1970 to 1990 probably carried out by blood transfusion. As described by Romano et al. [33] in Brazil, subtype 1b was the first HCV subtype introduced in Sao Paulo that possibly spread by blood transfusion and unsafe medical practices. Subtype $1 \mathrm{~b}$ was followed by subtype 3a, and finally subtype 1a was the last subtype to emerge.

Subtypes 1a and 3a have been related to IDU in some studies [10-13]. However the predominance of subtype 1a found among hemodialysis patients in Brazil and the risk of infection related with the length of the time on hemodialysis suggested nosocomial HCV transmission [34]. In the present study subtype 1a was found in two samples from patients with hemophilia, whereas subtype 3a was detected in one hemodialysis patient.

This dynamics of HCV was recently also demonstrated in a cohort of repeat donors in the USA in the period January 2006 through December 2009. Subtype 1a was the most frequent $\mathrm{HCV}$ genotype in prevalent and incident cases; subtype 3a strains were significantly more frequent in incident cases whereas subtype $1 \mathrm{~b}$ was less frequent in incident than in prevalent cases [8]. These results suggest that subtypes 1a and 3a have emerged recently and are spreading rapidly in some countries [10-13].

Additional studies and analysis of others HCV genome regions should be conducted in order to establish the phylogenetic relationship among HCV sequences obtained from Colombian blood donors, patients with chronic liver disease and multi-transfused patients [35]. The analysis of $\mathrm{HCV}$ sequences by genotype, clinical status, year of isolation and geographic origin could provide evidence of the $\mathrm{HCV}$ infection pattern spread in Colombia.

In conclusion, this is the first report on $\mathrm{HCV}$ genotypes among multi-transfused patients in Colombia where subtype $1 \mathrm{~b}$ was the most prevalent. The mutation G235A in the $5{ }^{\prime} \mathrm{UTR}$ of three $\mathrm{HCV}$ isolates generated an additional restriction site and, therefore, an RFLP pattern different from those previously described for genotype 1 . Although the number of samples analyzed is relatively small, 


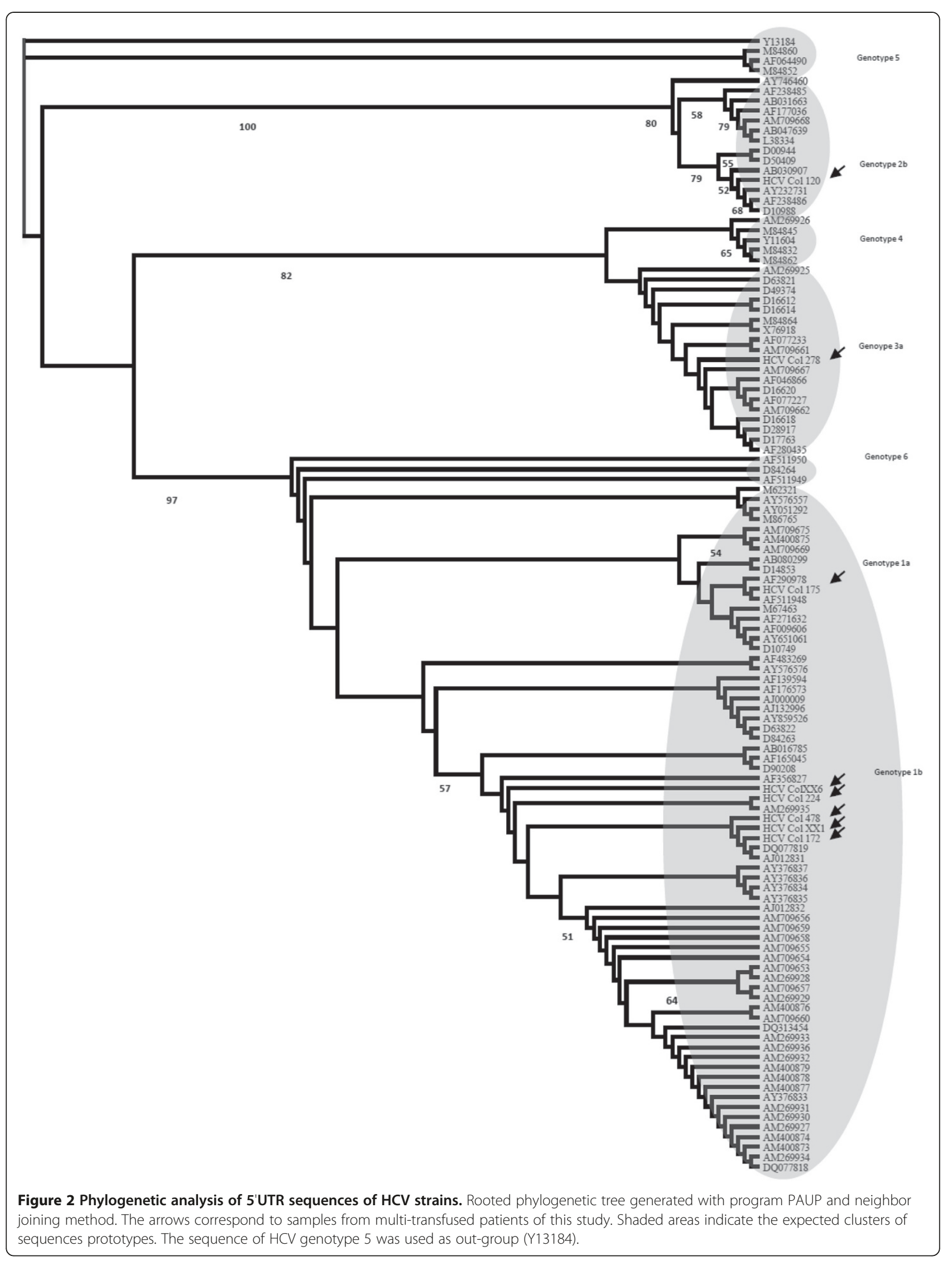




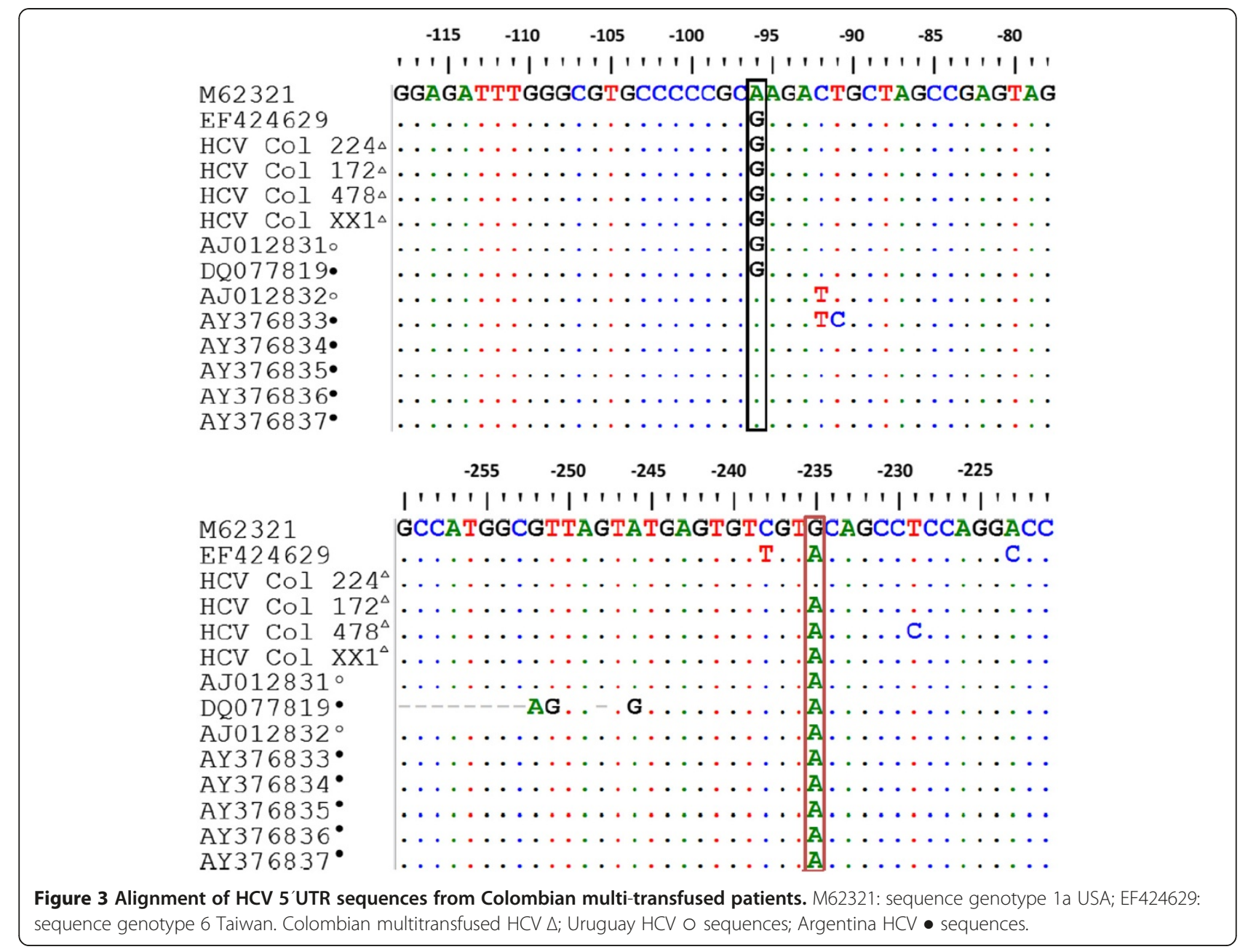

the results of this study have interesting implications regarding the $\mathrm{HCV}$ genotypes in a population exposed to blood transfusion during the time when TTI represented a serious health problem in Colombia. Molecular epidemiology studies are very important to understand the transmission dynamics of $\mathrm{HCV}$ infection in Colombia and in Latin America.

\section{Methods \\ Study population}

Five hundred multi-transfused patients were recruited at the Pan American Health Organization (PAHO) multicenter study between February and September 2003 in four hospitals of the two largest cities in Colombia, Bogota and Medellin. The present study was carried out with samples from 45 anti-HCV positive patients of this cohort.

The serum samples were stored at $-70^{\circ} \mathrm{C}$ in air tight vials with plug seal caps, since their collection in 2003, and not thawed until immediately before the analysis.

\section{Ethics statement}

All procedures adopted in this study were followed the terms established by the Ethics Committees of PAHO, Universidad de Antioquia, Instituto Nacional de Salud and Instituto Nacional de Cancerologia. The terms of informed consent were signed by all patients.

\section{Molecular detection of HCV}

Total RNA was extracted from samples using TRIzol LS Reagent (Invitrogen). The $5 \mathrm{HCV}$ 'UTR was detected by RT-nested PCR, as described by Chan et al. [36]. For cDNA synthesis, the viral RNA was reverse transcribed using primer 209 and Moloney Murine Leukemia Virus reverse transcriptase (Invitrogen). The 5'UTR was amplified by nested PCR using primers 209 and 939 and primers 940 and 211[36]. The amplified products were analyzed by agarose gel electrophoresis.

RFLP analysis and sequencing for genotype identification To determine the HCV genotype, RFLP analyses were performed as described by Davidson et al. [37] with 
some modifications. Briefly, the amplified products were digested in separate reactions with the restriction enzymes RsaI, HinfI or $\mathrm{MvaI}$ at $37^{\circ} \mathrm{C}$ for 1 hour, and thereafter with Bst $U I$ at $60^{\circ} \mathrm{C}$ for 1 hour. Two cycles of enzyme denaturation were then performed at $95^{\circ} \mathrm{C}$ for $10 \mathrm{~min}$. The digested products were analyzed by polyacrylamide gel electrophoresis. The genotype was determined by the pattern of each sample and compared with the predicted restriction patterns of $50 \mathrm{HCV}$ sequences available in GenBank, using the BioEdit 7.9.0.0 software (lbis Biosciences, Canada).

\section{Phylogenetic analysis of the HCV 5'UTR}

Phylogenetic analysis of the $5^{\prime}$ UTR sequences was carried out to identify the clade and subtype distribution. The amplified 5'UTR fragment was purified and sequenced (Macrogen, Korea) using the automated dideoxynucleotide method (BigDyeTM terminator). A total of 106 prototype $\mathrm{HCV}$ sequences available in GenBank were included in the analysis. Rooted neighbor-joining and maximum parsimony trees were constructed using the PAUP 4.0 (Phylogenetic Analysis Using Parsimony) and the Mega 4.1 (Molecular Evolutionary Genetics Analysis) software. Reliability of the trees was evaluated statistically by bootstrap analyses with 100 and 1000 replicates, respectively.

\section{Pair-wise comparison of HCV isolates}

HCV samples that exhibited no identifiable pattern by RFLP were sequenced and subjected to pair-wise comparisons. The sequence of each HCV sample was aligned with reference sequences using the BioEdit 7.9.0.0 software. Genbank accession numbers of reference sequences: Argentina isolates (DQ077819, AY376833, AY376834, AY376835, AY376836, AY376837), Uruguay isolates (AJ012831, AJ012832), and prototype sequences (M62321, EF424629, HCVCOL_224) of the genotypes $1 \mathrm{a}, 1 \mathrm{~b}$ and 6 , respectively.

\footnotetext{
Abbreviations

HCV: Hepatitis C virus; RFLP: Restriction fragment length polymorphism; 5 UTR: 5 'untranslated region; RT-PCR: Reverse transcriptase- polymerase chain reaction; IRES: Internal ribosome entry site; NJ: Neighbor-joining; MP: Maximum parsimony; BLAST: Basic Local Alignment Search Tool; cDNA: Copy DNA; ELISA: Enzyme-linked immunosorbent assay; TTI: Transfusion-transmissible infections; IDU: Intravenous drug users; elF3: Eukaryotic initiation factor 3.
}

\section{Competing interests}

The authors declare that they have no competing interests.

\section{Authors' contributions}

Conceived and designed the experiments: MCN, FCM. Performed the experiments: DdF, FCM. Analyzed the data: MCN, FCM, DdF, MB, MPA, SJ, GC, JCR. Wrote the paper: MCN, DdF, FC. All the authors have read and approved the final manuscript.

\section{Acknowledgements}

The authors wish to thanks Dr. Jose Ramiro Cruz from PAHO and Dr. Anne Lise Haenni from the Institut Jacques Monod for critical reading of the manuscript. This study was supported by the Universidad de Antioquia (Proyecto de sostenibilidad). The multicenter study in Latin America was supported by PAHO thanks to a grant from the Bill and Melinda Gates Foundation.

The authors also acknowledge the participation of Group EpiBlood Colombia at the multicenter study in Latin America. Grupo Epiblood Colombia:

Mauricio Beltrán ', Maria-Cristina Navas ${ }^{2}$, María Patricia Arbeláez ${ }^{3}$, Jorge Donado ${ }^{4}$, Sergio Jaramillo ${ }^{4}$, Fernando De la Hoz ${ }^{5}$, Cecilia Estrada ${ }^{6}$, Lucia del Pilar Cortés ${ }^{7}$, Gloria Barco ${ }^{4}$, Martha Luna ${ }^{6}$, Amalia de Maldonado ${ }^{8}$, Juan Carlos Restrepo ${ }^{2,4}$, Gonzalo Correa 2,4, Paula Borda ', Gloria Rey ', Marlen de Neira ${ }^{1}$, Angela Estrada ${ }^{4}$, Sandra Yepes ${ }^{4}$, Gustavo Adolfo Uribe ${ }^{6}$, Maria Mercedes Muñoz ${ }^{8}$, Oscar Beltrán ${ }^{7}$, Javier Pacheco ${ }^{8}$, Iván Villegas ${ }^{9}$, Jorge Boshell ${ }^{10} .{ }^{1}$ Instituto Nacional de Salud, Bogotá D.C., ${ }^{2}$ Grupo de Gastrohepatología, Universidad de Antioquia, Medellín, ${ }^{3}$ Grupo de Epidemiología, Universidad de Antioquia, Medellín, ${ }^{4}$ Hospital Pablo Tobón Uribe, Medellín, ${ }^{5}$ Facultad de Salud Pública, Universidad Nacional, Bogotá D. C., ${ }^{6}$ Instituto de los Seguros Sociales, Medellín, ${ }^{7}$ Instituto de los Seguros Sociales, Bogotá D.C., ${ }^{8}$ Banco de Sangre, Instituto Nacional de Cancerología, Bogotá D.C., ${ }^{9}$ Instituto del Riñón, Medellín, ${ }^{10}$ Banco de Huesos y Tejidos, Fundación Cosme y Damián, Bogotá D.C., Colombia.

\section{Author details}

${ }^{1}$ Grupo de Gastrohepatologia, Sede de Investigacion Universitaria (SIU), Universidad de Antioquia, Carrera 53 \# 61-30, Laboratorio 434, Torre 2, Medellin, Colombia. ${ }^{2}$ Facultad de Ciencias Exactas y Aplicadas, Instituto Tecnologico Metropolitano (ITM), Institucion Universitaria adscrita a la alcaldia de Medellín, Medellin CO-549 59, Colombia. ${ }^{3}$ Coordinacion Red Nacional de Bancos de Sangre, Instituto Nacional de Salud, Bogota, Colombia. ${ }^{4}$ Grupo de Epidemiologia. Facultad Nacional de Salud Publica, Universidad de Antioquia, Medellin, Colombia. ${ }^{5}$ Hospital Pablo Tobon Uribe, Calle 78B \# 69-240, Medellin, Colombia.

Received: 1 March 2012 Accepted: 19 October 2012

Published: 23 October 2012

\section{References}

1. Takada N, Takase S, Enomoto N, Takada A, Date T: Clinical backgrounds of the patients having different types of hepatitis $C$ virus genomes. $J$ Hepatol 1992, 14:35-40.

2. WHO: Global surveillance and control of hepatitis C. Report of a WHO consultation organized in collaboration with the viral hepatitis prevention board, antwerp, belgium. J Viral Hepat 1999, 6:35-47.

3. Choo QL, Richman KH, Han JH, Berger K, Lee C, Dong C, Gallegos C, Coit D, Medina-Selby R, Barr PJ, Weiner AJ, Bradley DW, Kuo G, Houghton M: Genetic organization and diversity of the hepatitis C virus. Proc Natl Acad Sci U S A 1991, 88:2451-2455.

4. Penin F, Dubuisson J, Rey FA, Moradpour D, Pawlotsky JM: Structural biology of hepatitis C virus. Hepatology 2004, 39:5-19.

5. Sanchez JL, Sjogren MH, Callahan JD, Watts DM, Lucas C, Abdel-Hamid M, Constantine NT, Hyams KC, Hinostroza S, Figueroa-Barrios R, Cuthie JC: Hepatitis C in Peru: risk factors for infection, potential iatrogenic transmission, and genotype distribution. AmJTrop Med Hyg 2000, 63:242-248

6. Simmonds P: Genetic diversity and evolution of hepatitis C virus-15 years on. J Gen Virol 2004, 85:3173-3188.

7. Simmonds P, Mellor J, Sakuldamrongpanich T, Nuchaprayoon C, Tanprasert S, Holmes EC, Smith DB: Evolutionary analysis of variants of hepatitis C virus found in South-East Asia: comparison with classifications based upon sequence similarity. J Gen Virol 1996, 77(Pt 12):3013-3024.

8. Delwart E, Slikas E, Stramer SL, Kamel H, Kessler D, Krysztof D, Tobler LH, Carrick DM, Steele W, Todd D, Wright DJ, Kleinman SH, Busch MP: Genetic diversity of recently acquired and prevalent HIV, hepatitis B virus, and hepatitis C virus infections in US blood donors. J Infect Dis 2012, 205:875-885.

9. Zein NN: Clinical significance of hepatitis C virus genotypes. Clin Microbiol Rev 2000, 13:223-235.

10. Dubois F, Desenclos JC, Mariotte N, Goudeau A: Hepatitis C in a french population-based survey, 1994: seroprevalence, frequency of viremia, genotype distribution, and risk factors. The Collaborative Study Group. Hepatology 1997, 25:1490-1496.

11. Pawlotsky JM, Tsakiris L, Roudot-Thoraval F, Pellet C, Stuyver L, Duval J, Dhumeaux D: Relationship between hepatitis $C$ virus genotypes and 
sources of infection in patients with chronic hepatitis C. J Infect Dis 1995, 171:1607-1610.

12. Pybus OG, Cochrane A, Holmes EC, Simmonds P: The hepatitis $C$ virus epidemic among injecting drug users. Infect Genet Evol 2005, 5:131-139.

13. Silini E, Bono F, Cividini A, Cerino A, Maccabruni A, Tinelli C, Bruno S, Bellobuono A, Mondelli M: Molecular epidemiology of hepatitis C virus infection among intravenous drug users. J Hepatol 1995, 22:691-695.

14. van den Burg PJ, Vrielink H, Reesink HW: Donor selection: the exclusion of high risk donors? Vox Sang 1998, 74(Suppl 2):499-502.

15. Williams AE, Thomson RA, Schreiber GB, Watanabe K, Bethel J, Lo A, Kleinman SH, Hollingsworth CG, Nemo GJ: Estimates of infectious disease risk factors in US blood donors. Retrovirus epidemiology donor study. JAMA 1997, 277:967-972.

16. Schmunis GA, Cruz JR: Safety of the blood supply in latin america. Clin Microbiol Rev 2005, 18:12-29.

17. Beltran M, Navas MC, De la Hoz F, Mercedes Munoz M, Jaramillo S, Estrada C, Del Pilar Cortes L, Arbelaez MP, Donado J, Barco G, Luna M, Uribe GA, de Maldonado A, Restrepo JC, Correa G, Borda P, Rey G, de Neira M, Estrada A, Yepes S, Beltran O, Pacheco J, Villegas I, Boshell J: Hepatitis C virus seroprevalence in multi-transfused patients in Colombia. J Clin Virol 2005, 34(Suppl 2):S33-S38.

18. Mora MV, Romano CM, Gomes-Gouvea MS, Gutierrez MF, Carrilho FJ, Pinho JR: Molecular characterization, distribution, and dynamics of hepatitis C virus genotypes in blood donors in Colombia. J Med Virol 2010, 82:1889-1898

19. Schmunis GA, Zicker F, Cruz JR, Cuchi P: Safety of blood supply for infectious diseases in latin american countries, 1994-1997. AmJTrop Med Hyg 2001, 65:924-930.

20. Gismondi MI, Becker PD, Valva P, Guzman CA, Preciado MV: Phylogenetic analysis of previously nontypeable hepatitis $C$ virus isolates from Argentina. J Clin Microbiol 2006, 44:2229-2232.

21. Gismondi Ml, Staendner LH, Grinstein S, Guzman CA, Preciado MV: Hepatitis $C$ virus isolates from Argentina disclose a novel genotype 1-associated restriction pattern. J Clin Microbiol 2004, 42:1298-1301.

22. Babaylova E, Graifer D, Malygin A, Stahl J, Shatsky I, Karpova G: Positioning of subdomain IIId and apical loop of domain II of the hepatitis C IRES on the human 40S ribosome. Nucleic Acids Res 2009, 37:1141-1151.

23. Lytle JR, Wu L, Robertson HD: Domains on the hepatitis $C$ virus internal ribosome entry site for 40s subunit binding. RNA 2002, 8:1045-1055.

24. Siridechadilok B, Fraser CS, Hall RJ, Doudna JA, Nogales E: Structural roles for human translation factor elF3 in initiation of protein synthesis. Science 2005, 310:1513-1515.

25. Botero RC, Rojas E, Idrovo V, Ponce E, Sierra F: Genotipos del virus de la Hepatitis C (HCV) en Santa Fé de Bogotá. Rev Colomb Gastroenterol 1997, 12:15-20.

26. Correa G, Yepes A, Alvarez C, Restrepo JC, Zapata JC, Arango A: Genotipos virales en pacientes con infección por el virus de la hepatitis $C$ en medellín. Gastroenerología y Hepatología 2002, 25:333-336.

27. Cortés A, Beltrán M, Olaya B, Hernández M: Riesgo de enfermedades infecciosas transmitidas por transfusión en el Valle del Cauca. Colomb Med 1999, 30:13-18.

28. Santamaria C, Delima E, Holguín J: Hallazgos histológicos en infección crónica por el virus de la Hepatitis C y su correlación con el genotipo viral, en Cali. Colombia. Medical 1998, 29:20-23.

29. Cortes-Mancera F, Loureiro CL, Hoyos S, Restrepo JC, Correa G, Jaramillo S, Norder H, Pujol FH, Navas MC: Etiology and viral genotype in patients with End-stage liver diseases admitted to a hepatology unit in colombia. Hepat Res Treat 2011, 2011:363205.

30. Djebbi A, Bahri O, Langar H, Sadraoui A, Mejri S, Triki H: Genetic variability of genotype 1 hepatitis $C$ virus isolates from Tunisian haemophiliacs. New Microbiol 2008, 31:473-480.

31. Ferreira MR, Lonardoni MV, Bertolini DA: Hepatitis C: serological and molecular diagnosis and genotype in haemophilic patients at the Regional Hemocenter of Maringa, Maringa PR Brazil. Haemophilia 2008, 1-6.

32. Beltrán MAM, Ching R: Situación actual del tamizaje en bancos de sangre. Biomedica 1997, 16:51-52.

33. Romano CM, de Carvalho-Mello IM, Jamal LF, de Melo FL, lamarino A, Motoki M, Pinho JR, Holmes EC, de Andrade Zanotto PM: Social networks shape the transmission dynamics of hepatitis $C$ virus. PLoS One 2010, 5:e11170.
34. Freitas SZ, da Cunha RV, Martins RM, Teles SA, Ibanhes ML, Motta-Castro AR: Prevalence, genotypes and risk factors associated with hepatitis $C$ virus infection in hemodialysis patients in Campo Grande, MS, Brazil. Mem Inst Oswaldo Cruz 2008, 103:405-408.

35. Dencs A, Hettmann A, Martyin T, Jekkel C, Banyai T, Takacs M: Phylogenetic investigation of nosocomial transmission of hepatitis $C$ virus in an oncology ward. J Med Virol 2011, 83:428-436.

36. Chan SW, McOmish F, Holmes EC, Dow B, Peutherer JF, Follett E, Yap PL, Simmonds $P$ : Analysis of a new hepatitis $C$ virus type and its phylogenetic relationship to existing variants. J Gen Virol 1992 73(Pt 5):1131-1141.

37. Davidson F, Simmonds P, Ferguson JC, Jarvis LM, Dow BC, Follett EA, Seed CR, Krusius T, Lin C, Medgyesi GA, et al: Survey of major genotypes and subtypes of hepatitis $C$ virus using RFLP of sequences amplified from the 5' non-coding region. J Gen Virol 1995, 76(Pt 5):1197-1204.

doi:10.1186/1743-422X-9-242

Cite this article as: di Filippo et al:: Molecular characterization of hepatitis c virus in multi-transfused Colombian patients. Virology Journal 2012 9:242.

\section{Submit your next manuscript to BioMed Central and take full advantage of:}

- Convenient online submission

- Thorough peer review

- No space constraints or color figure charges

- Immediate publication on acceptance

- Inclusion in PubMed, CAS, Scopus and Google Scholar

- Research which is freely available for redistribution 